\title{
The Uniqueness of Family Firms
}

\author{
Harijono \\ Satya Wacana Christian University \\ Jl. Diponegoro, Salatiga - Central Java - Indonesia
}

\begin{abstract}
This study focuses on family business theory from two theories of the firm perspectives: the incomplete contract and the agency perspectives. It shows that families represent a special class of large shareholders that potentially have a unique incentive structure and power in the firm. The unique characteristics of family firms potentially make their performance and their corporate decisions making different from those of non-family firms. The empirical evidences tend to support this argument. However, further quantitative and qualitative research to establish the relations between family control and several aspects of corporate decision making in different institutional and cultural settings remains to be done
\end{abstract}

Keywords: Agency, Control, Cultural, Family Business, Investment, Shareholders

\section{INTRODUCTION}

Two key aspects of corporate ownership structure are concentration and composition (Capulong et al., 2000). The degree of ownership concentration in a company determines the distribution of power between its managers and shareholders. When ownership is dispersed, shareholder control tends to be weaker. In contrast, shareholders can play an important role in monitoring management when ownership is concentrated. A second key aspect of corporate ownership structure is its composition, namely the makeup of the controlling shareholders. As noted by Holderness and Sheehan (1988) and Gugler (2001), each type of large shareholder might have different incentives and motivations. Unfortunately, "academic studies and public debates have generally ignored the identity of large-block shareholders" (Holderness and Sheehan, 1988, p. 323).

Recently La Porta et al. (1999) documented that most firms in the world are controlled by families. Such family ownership is not only nearly universal among privately held firms, but is also prevalent among publicly traded firms. In Western Europe, South and East Asia, Middle East, Latin America, and Africa, the vast majority of publicly traded firms are family controlled (La Porta et al., 1999; Claessens et al., 2002; Faccio and Lang, 2002). Claessens et al. (2002) reported that more than 50 percent of publicly traded corporations in East Asian countries are controlled by a family, while Faccio and Lang (2002) documented that nearly 50 percent of public firms in Western Europe are under family control.

Even in the United States where it is believed that firms are dominated and controlled by professional managers (Morck and Yeung, 2003), the role of family firms is not insignificant. While examining the Standard \& Poor's top 500 firms in the U.S. from 1992 through 1999, Anderson and Reeb (2003a) observe that founding families are a prevalent and important class of investors in 
most industry groups. Family firms comprise over 32 percent of the S\&P 500 Industrials and on average families own nearly 18 percent of their firms' outstanding equity.

Due to its economic significance, family firms deserve special attention from researchers. However, very little is known about how these businesses differ from those owned by other types of shareholders, for it is only in the last decade that serious academic research on family firms has been undertaken (Chami, 1999). This paper is part of a growing interest in family business research. Specifically, the study focuses on family business theory from theory of the firm perspectives. The paper is organized into 3 sections. The first section reviewed literature related to theory of the firm from two points of view: the incomplete contract and the agency perspectives. In the next section, these perspectives are applied to family firms. Finally, the uniqueness of family firms and its impact on corporate decision is identified.

\section{THEORY OF THE FIRM}

A pure analysis of the neoclassical price theory leaves almost no room for the firm (Foss et al., 2000). The theory describes how markets may produce efficient outcomes. The question how organisations should be structured does not arise, because marketcontracting perfectly solves all incentive and coordination issues. By assumption, firm behaviour (profit maximisation) is invariant to institutional form (for example, ownership structure).

Coase (1937) raised a very important question for neoclassical price theory: if price system is the ideal structure for carrying out economic coordination, why does so much economic activity take place outside the price system (i.e., within firms in which market transactions are replaced by centralised direction)? He then reasoned that there must be costs associated with using the market that can be eliminated by using the firm. These costs are known as transaction costs.

From Coase's initial insight, economists took the theory of the firm in two different directions. The first approach, incomplete contracting/property rights model, focuses on circumstances in which it might be less costly to organize production within a firm. A central question here is what factors might increase the transaction costs of organising activities through market transactions? One answer is opportunism in the presence of investments in specialised assets. The second approach, the agency model, stresses the importance of agency problems and how firms provide a mechanism to control this issue.

Foss et al. (2000) argue that each division of the theory of the firm concentrates on different kinds of transaction costs that Coase (1937) identified. They also maintain that these perspectives are complementary and should be integrated.

\section{Incomplete contract/property rights model.}

If firms exist to reduce transaction costs, how does control of firm become a key factor? Williamson (1975) identified several characteristics of transactions that make it costly to organise through markets. Where these features apply, transacting parties might choose to administer such transactions within the firm. The most important feature is what he called the asset-specificity of investment, which refers to the degree of difficulty in redeploying assets for other uses.

A relationship-specific asset is an investment made to support a given transaction. These assets are often essential for the efficiency of a particular transaction. However, a relationship-specific asset cannot be redeployed to another transaction without some sacrifice in the productivity of the asset 
or some cost in adapting the asset to the new transaction. The need to create relationshipspecific assets transforms the relationship as the transaction unfolds. Before the relationship-specific investments are made, a party may have many alternative trading partners, which allows competitive bidding. But after the relationship-specific investments have been sunk, competitive bidding is no longer possible. That is, when a transaction involves relationship-specific assets, parties to the transaction cannot costlessly switch trading partners. This implies that investments in relationship-specific assets lock the parties into the relationship (Besanko et al., 2004). Williamson (1985) has referred to this change as the fundamental transformation.

Asset specificity can take several forms (Williamson, 1985): site specificity (assets that are located in a particular area and cannot be moved easily); physical asset specificity (assets whose physical or engineering properties are specifically tailored to a particular transaction); dedicated assets (an investment in plant and equipment made to satisfy particular buyer) and human asset specificity (skills, know-how, and information acquired by people that are more valuable inside a particular relationship than outside it).

When a firm invests in a relationshipspecific asset, the quasi-rent must be positive. The quasi-rent of relationship-specific assets equals the extra profit a firm gets when it deploys its assets for their intended use, as opposed to deploying those assets for their best alternative use. If quasi-rent is large, a firm loses a lot of its rent and it turns to its second-best alternative. In contrast, the profit the firm could get from using the generic asset in its best alternative and its next best alternative would be the same, and therefore, the associated quasi-rent would be zero (Besanko et al., 2004).

The large quasi-rent opens the possibility for hold-up problems (Klein et al.,
1978) or opportunistic behaviours

(Williamson, 1985). A trading partner holds up one particular firm by attempting to renegotiate the terms of a deal. Knowing that the asset cannot be used elsewhere without significant loss, the trading partner might force a firm to reduce the transaction price. In doing so, the trading partner grabs some of the returns of the investment that the firm hopes to earn.

The following simple example provided by Barney (2002) explains the holdup and quasi-rent concepts. If Firm A invests in a special technology that can be used only in an exchange with Firm B, Firm A has made a transaction-specific investment. Firm B can, however, exploit the specific investment made by Firm A. The economic value of this exploitation can be as much as the difference between the value of this investment for its first best use and the value for its second best use. If the value of this investment is its highest use value (i.e., in the exchange between Firm A and Firm B) and is $\$ 10,000$, and its next-highest value (i.e., in the exchange not between Firm A and Firm B) is only \$500, then Firm B can appropriate economic value from Firm A up to $\$ 9,500$ (project quasi-rent). As long as the value of the appropriation is less than $\$ 9,500$, it is still better for Firm A, which made the specific investment to continue in this exchange rather than cancel the exchange and thereby gain only $\$ 500$.

Hold-up problems (or opportunistic behaviours) do not exist in a world of complete contracts (Klein et al., 1978; Williamson, 1985). A complete contract stipulates each party's responsibilities and rights for each and every contingency that can conceivably arise during the transaction. Neither party can exploit weaknesses in the other's position while the transaction is in progress. However, boundedly rational people cannot enumerate every contingency that might arise during the period a transaction is in effect. As a result, 
they write incomplete contracts. An incomplete contract does not fully specify the "mapping” for every possible contingency of rights, responsibilities, and actions. Virtually all real-world contracts are incomplete and therefore, there always exists a possibility of hold-up.

The possibility of hold-up can reduce incentives to invest in specific assets. The tendency to underinvest in relationshipspecific assets causes problems because relationship-specific assets usually allow firms to achieve efficiency that cannot be achieved with general-purpose investments. When holdup problems lead to underinvestment in relationship-specific assets, the result is likely to be lower productivity and higher production costs (Besanko et al., 2004).

The potential hold-up problems would encourage the contracting parties to integrate their operations into a single corporation (Blair, 1995). Blair provides a simple example to illustrate the relation between hold-up problems and the existence of firms. Suppose one party owns a coal mine and the other party owns a power plant built at the mouth of the coal mine designed to use coal from the mine. The two parties would probably find themselves in frequent disputes about the price and terms on which the coal is to be sold to the power plant. But if a single party owns both the mine and the power plant, the owner would maximise the joint return and not waste resources haggling over the terms of trade between the two units. In short, integration of activities into a single corporation occurs when renegotiation costs are high and when important relationship-specific investments exist.

While these theories are clear on the costs of transacting in the market place with incomplete contracts (i.e., hold-up problem), they are somewhat ambiguous about the benefits of integrating activities into a single firm. Grossman and Hart (1986) and Hart and
Moore (1990) provide a more formal framework, referred to as a property rights approach to the theory of the firm. They view ownership of a firm as giving the owner residual control rights over the use of the firm's assets; that is, the right to use assets in whatever way the owner likes unless otherwise prohibited in a contract. In particular, the owner of an asset has the right to exclude others from its use (Bolton and Scharftstein, 1998). With this power, owners of particular assets have stronger bargaining positions in the distribution of quasi-rents from relationshipspecific assets. Therefore, the benefit of ownership is to encourage parties to make investments in productive specific assets.

\section{Agency Model.}

Grossman and Hart (1986) define ownership as a residual control right, that is, the right to make decisions when not specified in a contract. With this right, owners have the power to determine how assets are deployed. In short, in a property rights paradigm, ownership is synonymous with control. The property rights theory perspective also demonstrates how the distribution of control affects the division of surplus and hence economic decision-making.

Berle and Means (1932) add another important perspective on the theory of the firm by introducing the concept of the separation of ownership from control. Unlike the property rights paradigm, Berle and Means implicitly define ownership as claims made on the firm's residual cash flow (i.e., the cash flow that is available after paying other stakeholders). They observed that most U.S. corporations are owned by widely dispersed shareholders. Dispersed shareholders have a low incentive to monitor managers due to the free rider problem (i.e., a dispersed shareholder is not interested in monitoring because he/she bears all the monitoring costs and only shares a small proportion of the benefit). As a result, 
the effective control of corporations ends up in the hands of management.

The concept of the separation of ownership and control is the starting point for agency theory. In its paradigmatic version, the theory deals with the relationship between a principal (e.g., the shareholder) and an agent (e.g., the manager) who works on a welldefined task.

An analysis of the agency problem is based on two fundamental behavioural assumptions (Barnea et al., 1980). First, all individuals are assumed to choose actions that maximise their own personal welfare. As a consequence, as decision-making authority is delegated by the principal to an agent, agents use this power to promote their own well being. Actions chosen by agents to achieve this goal may or may not be in the best interest of the principal. Second, individuals are assumed to be rational and capable of forming unbiased expectations regarding the impact of the agency problem and its associated effect on the future value of their wealth. Rationality implies that every individual recognises the self-interest motivations of others. In other words, future decisions by agents are based on their own self-interest and these decisions are anticipated and taken into account by the principal.

Another basic assumption in agency theory is that some information asymmetry exists between the principal and the agent, so that the principal cannot directly observe the activities of the agent or that the agent knows some other aspect of the situation which is unknown to the principal. As the interest of principals and agents are sometimes misaligned, agents might maximise their self interest even at the expense of principals. The problems due to this divergence of interest are referred to as the agency problem.

From its roots in information economics, agency theory has developed along two lines: positivist and principal-agent 40
(Jensen, 1983). The two streams share a common unit of analysis: the contract between principal and agents. They also share common assumptions about people, organisations and information. However, they differ in their mathematical rigor, dependent variable, and style (Eisenhart, 1989).

The focus of the principal agent literature is on determining the optimal contract between the principal and the agent (Eisenhart, 1989). In the case of unobservable behaviour (due to moral hazard or adverse selection), the principal has two options. One is to discover the agent's behaviour by investing in information systems such as budgeting systems, reporting procedures, board of directors, and additional layers of management. Such investments reveal the agent's behaviour to the principal and the situation reverts to the complete information case. The other option is to contract the outcomes of the agent's behaviour. Such outcome-based contracts motivate compliance of behaviour by coalignment of the agent's preferences with those of the principal, but at the price of transferring risks to the agent.

Positivist researchers, pioneered by Alchian and Demsetz (1972) and Jensen and Meckling (1976), have focused on identifying situations in which the principal and agent are likely to have conflicting goals and then describing governance mechanisms that limit the agent's self-serving behaviour. Positivist researchers have focused almost exclusively on the special case of the principal-agent relationship between owners and managers at large, specifically in public corporations.

Alchian and Demsetz (1972) explain that firms exist because of team production. Team production is a situation in which two (or more) people can produce more when they are working together than when they are working separately. The problem is that people working in teams and sharing the proceeds of their work will put in lower levels of effort 
than persons who are self-employed. This phenomenon is called shirking. Every team member will be tempted to engage in shirking and therefore, the total output of the team will be much lower than if there was no shirking.

According to Alchian and Demsetz (1972), a solution to the shirking problem is to appoint a monitor. If the monitor is to be effective, he/she must have the power to revise the terms the contract of individual team members. The monitor must have the right to terminate contracts with team members, to attract new team members and to adjust wage rates of every team member. Finally, the monitor also must have the right to sell his/her rights as monitor. In other words, the monitor is the owner of the firm; he/she receives the residual, has the right to sell his/her firm, has the right to hire and fire team members, and to adjust their wages individually (Douma and Schreuder, 2003). In short, Alchian and Demsetz argue that the firm primarily exists as a solution to moral hazard behaviour in team productions.

Jensen and Meckling developed a theory on how ownership structure of the firm affects the behaviour of managers of firms. They argue that firms are simply legal fictions, which serve as a nexus for a set of contracting relationships among individuals. In particular, firms should be viewed as contracting mechanisms between the providers of capital (the principals) and managers (the agents) designed to minimise the agency costs of this relationship.

Jensen and Meckling break down agency costs into three components: first, by monitoring the principal's expenditure; second, bonding expenditure of the agent, and third, the residual loss. Monitoring expenditures are paid by the principal to regulate the agent's conduct. Bonding expenditures are created by the agent to ensure that he/she will not take actions which damages the principal. The residual loss is the value of the loss by the principal from decisions by the agent, which deviate from decisions made by the principal if he had the same information and talents as the agent.

It is important to recognise that the contracting parties bear the agency costs associated with their interaction and therefore have the incentive to structure contracts to reduce agency costs wherever possible (Smith, 1990). Contracting parties gain from forecasting accurately the action to be undertaken and structuring the contracts to facilitate the expected actions. For example, with competitive and informationally efficient financial markets, unbiased estimates of agency costs should be included in the price of securities when they are initially offered (as well as at any future date). This mechanism provides incentives to structure contracts and institutions to lower agency costs.

$$
\text { Jensen and Meckling }
$$

particularly concentrated on models which analysed the impact of conflict between managers and shareholders and conflict between shareholders and debtholders on issues related to optimal capital structure. In essence, Jensen and Meckling argue that optimal capital structure is determined at the point where the marginal benefit of using debt to control manager-shareholder conflict intersects with the marginal cost of shareholder-debtholder conflict. This is explored in more detail in Section 2.4 (Capital Structure Theory).

In the mid-1980s researchers in the U.S. began to uncover that a significant proportion of large corporations were not widely-held firms (Holderness, 2003). In other words, concentrated stock ownership is quite prevalent among large corporations. These findings led to the concept of ownership structure, which is the most important factor that determines the nature of the agency problem (Capulong et al., 2000). That is, ownership structure affects whether dominant 
conflict is between managers and shareholders, or between controlling and minority shareholders.

The first aspect of ownership structure that emerges in the finance literature is ownership concentration. The degree of ownership concentration in a company determines the distribution of power between its managers and shareholders. When ownership is dispersed, shareholder control tends to be weaker because of poor shareholder monitoring. The primary agency problem in this type of firm is conflict between shareholders and managers. When ownership is concentrated, on the other hand, large shareholders play an important role in monitoring management. However, a fundamental problem in corporate governance under concentrated ownership is how to protect minority shareholders from expropriation by controlling shareholders. Controlling shareholders might act in their own interests at the expense of minority shareholders and other investors (Capulong et al., 2000).

A second key aspect of corporate ownership structure is its composition, namely, the make up of its shareholders. A shareholder can be an individual, a family or family group, a holding company, a bank, an institutional investor such as a finance company, an insurance company, an investment company, a pension fund, or a mutual fund, or a non-financial corporation. Capulong et al. (2000) argue that a family would more likely be interested in the control benefits as well as profits, whereas an institutional investor is more likely to be interested only in profits. In short, each type of large shareholder has different incentives and motives (Holderness and Sheehan, 1988; Gugler, 2001), which provides a fundamental argument used in the context of this paper.

\section{Family Business Theory}

The previous section reviewed literature related to theory of the firm from two points of view: the incomplete contract and the agency perspectives. In this section, these perspectives are applied to family business theories. In particular, the opposing views on advantages to family business are discussed through the prism of agency and incomplete contract theories.

\section{Incomplete contract/property rights perspective.}

Zingales (1998) outlines a theory of corporate governance based on the incomplete contract paradigm discussed above. He argues that any governance mechanism such as family control, allocation of ownership, capital structure, managerial incentive schemes, takeovers, boards of directors, pressure from institutional investors, product market competition, labour market competition, organisational structure, etc., can all be thought of as institutions that affect the process through which quasi-rents are distributed.

In a perfect market it is assumed that agents can costlessly write all state-contingent contracts. As a result, all decisions are made ex-ante and all quasi-rents are allocated exante. Thus, there is no room for governance. However, due to bounded rationality all contracts are most likely to be incomplete. That is, the contract does not fully specify the division of surplus in every possible contingency. As a result, there is a need for a complex set of constraints that shape the $e x$ post bargaining over the quasi-rents generated in the course of a relationship (i.e., governance system).

In short, Zingales (1998) proposes two necessary conditions for a governance system. First, the relationship must generate some quasi-rents. In the absence of quasi-rents, the competitive nature of the market will eliminate 
any scope for bargaining. Second, the quasirents are not perfectly allocated ex-ante. If they were, then there would be no scope for bargaining either.

Another important concept in the incomplete contract model is the residual rights of control introduced by Grossman and Hart (1986). In a world of incomplete contracts, it is necessary to allocate the right to make ex-post decisions in unspecified contingencies. This residual right is both meaningful and valuable. It is meaningful because it confers the discretion to make decisions ex-post. It is valuable because this dis cretion can be used strategically in bargaining over the surplus.

The residual rights of control provide justification why shareholders should be in control (Zingales, 1998). The owner of a firm will generally be the party with the most expropriable investment (i.e., the owners quasi-rents are appropriable due to the hold-up problem). By contrast, productive assets (plant and equipment; human capital) of suppliers normally remain in the suppliers' possession. Thus, other stakeholders have a better outside option during the ex-post bargaining and they do not need the protection ensured through the residual rights of control. Therefore, control should be allocated to shareholders so as to maximise the incentives to make firm-specific investments.

Accordingly, it can be argued that family control is meaningful and valuable in the world of incomplete contracts for two reasons. First, families have two important types of investments in the firm, financial capital (which carries both a right to vote as a residual claimant and a right to the firm's cash flows) and human capital (which carries neither voting nor cash flow rights). It is the human capital portion which is appropriable (Cheung and Gaa, 1989). In order to protect this valuable firm-specific investment, families have to retain control.
Becker's (1964) classification of human capital suggests that the management function consists of three types of skills: generic skills, industry-specific skills and firmspecific skills. Generic skills form the basis of management function; all managers should have these skills, which can be transferred across all businesses and firms. A manager can transfer industry-specific skills only to firms that operate in the same industry. In contrast, managers are unable to transfer firm-specific skills outside the firm (Harris and Helfat, 1997).

Firm-specific skills include an indepth understanding of factors such as the company's history, culture, important personal business contacts and networks, the ability to garner the cooperation of the firm's workforce, and knowledge about local conditions and internal operations of the family business. It is firm-specific human capital that usually allows firms to achieve efficiency that cannot be achieved with general-purpose skills. Indeed, firm-specific skills may be the key success factor to firm competitiveness and performance. From the incomplete contract perspective, firm-specific investments generate so-called quasi-rents (i.e., the difference in an asset's value from the first to the second highest valuing user). Unfortunately, quasirents are potentially appropriable by others through hold-up or opportunistic behaviour (Klein et al., 1978; Williamson, 1985).

The strongest threat to quasi-rents of firm-specific human capital comes from rentseeking outsiders desiring control of the firm (Castanias and Helfat, 1992). If an outsider is able to takeover the company and dismiss the incumbent management, the incumbent management loses the rent that they expected to generate from investing in firm-specific human capital. Thus, firm-specific human capital is less valuable in other firms. Therefore, quasi-rents of firm-specific skills 
and decisions are at risk of appropriation by takeover raiders.

$$
\text { DeAngelo and DeAngelo (1985) argue }
$$
that families hold majority votes in order to more firmly define their property rights and to maximise returns on their investments in organisation-specific human capital. The benefit from managerial vote ownership in this case is substantially identical to that revealed by the standard economic analysis of the patent problem. As returns from innovation are potentially appropriable through future competition, the patent analysis indicates that reduced exposure to such competition yields benefits by encouraging investment in innovation. In a public corporation, vote ownership can shield incumbent managers from competition affected through vote accumulation by outsiders. Majority vote ownership can thus encourage managers to invest in organisation-specific capital, whose returns are potentially appropriable if outside stockholders can transfer control to another management group.

Another reason why family control is valuable is it is impossible to divide quasirents ex-ante in incomplete contract world. That is, incomplete contracts provide room for ex-post bargaining. By maintaining control, family shareholders have a strong bargaining position in dividing quasi-rents, which are closely related to the concept of private benefits of control.

Voting power that gives shareholders the capacity to influence management is used to consume corporate resources and to enjoy corporate benefits that are not shared with minority shareholders. Since the benefits only accrue to blockholders, they are called the private benefits of control (Barclay and Holderness, 1992).

Dyck and Zingales (2003) provide two good examples of how a controlling shareholder can simply transfer resources from the firm for his/her own benefit through self- dealing transactions. The "fair" transfer price of a certain asset or product may be subjective. As a result, small deviations from the "fair" transfer price might be difficult or impossible to verify in court. If these small deviations are applied to large trade volumes, however, they can easily generate sizeable private benefits. Similarly, it is easy to disagree over who is the best provider of an asset or product when the relationship might involve considerations of quality and price.

The second example relates to the ability to get inside information from the firm and exploit business opportunities through other companies. Controlling shareholders usually have access to inside information. Some of this information may reflect potential opportunities in other more or less related areas. It is easier for a controlling shareholder to choose to exploit these opportunities through another company he/she is associated with, with no advantage for the remaining shareholders. The net present value of these opportunities represents a private benefit of control.

Other examples of private benefits of control are empire building, expense accounts and extravagance, inter-corporate loans at nonmarket rates, use of the firm's money and name to lobby politicians to promote controlling shareholders social and political agendas (Mayer, 2001). Many examples of private benefits of control are unique to family firms. For example, family control provides flexibility to hire family and relatives, to transfer firms to heirs and to enhance the family name (DeAngelo and DeAngelo, 1985; Anderson et al., 2003). A common feature of these examples is that value is not shared among all the shareholders in the same proportion to the shares owned, but is enjoyed exclusively by the party in control. Hence, it is called private benefits of control (Dyck and Zingales, 2003). 
Whether private benefits of control are socially beneficial or not is debatable. Ehrhardt and Nowak (2003) argue that any benefits of control not shared with minority shareholders gives controlling shareholders an incentive to deviate from the maximisation of total firm value. Private benefits of control are cited as a source of the negative impact of family control on firm performance in East Asia (Faccio et al., 2001; Claessens et al., 2002). Due to poorly developed corporate governance systems in East Asia, private benefits of control in this region can be seen in the form of empires, cronyism, corruption and crime through mechanism such as zaibatsu firms in pre-war Japan, chaebols in Korea, excessive conglomeration in Indonesia etc. (Mayer, 2001).

Holderness (2003) argues that private benefits do not necessarily reduce the wealth of minority shareholders. For example, neither nonpecuniary benefits nor synergies in production that result if a corporation is the blockholder (a common situation) reduce the wealth of minority shareholders. Indeed, both of these private benefits could provide benefits to minority shareholders; both types of private benefits of control could, in other words, produce shared benefits of control. In addition, Grossman and Hart (1980) suggest that even if the extraction of private benefits generate some inefficiencies, its existence might be socially beneficial because its presence makes value-enhancing takeovers possible.

In the case of family firms, Mayer (2001) argues that the promotion and protection of the family name does not involve investor expenditure. They do not directly benefit investors, but they might encourage actions and activities that indirectly do so. Dennis and Dennis (1994) also argue that the desire to enhance the family name and to pass on enterprises to heirs can provide an important constraint on managerial selfdealing, enabling owners of these types of firms to realise large private benefits of control of their corporation without sacrificing the performance of a firm.

In short, from an incomplete contract perspective, family control exists because it protects valuable firm-specific human capital and it enables families to enjoy the private benefits of control. Whether family control is socially beneficial is still debatable because it has both advantages and disadvantages.

\section{Agency Perspective.}

Agency theory provides a mixed view on family firms. Jensen and Meckling (1976) theorise that agency costs are much lower in firms where the owners and managers are effectively the same party. This is because less monitoring of the owners' agents is needed. Therefore, family firms would be particularly efficient due to reduced agency costs. This assumption is so strongly held that the ownermanaged firm is used as the zero agency cost base by finance researchers (Ang et al., 2000). However, recent research suggests that agency issues in family firms are more complex than previously believed (Gomez-Mejia et al., 2003; Steier, 2003). Specifically, entrenched ownership and asymmetric altruism within family firms create their own unique agency problems (Gomez-Mejia et al., 2001; Schulze et al., 2001).

The dispersion of ownership in larger corporations separates ownership from control, that is, shareholders delegate decision-making authority to managers. The separation of ownership from control leads to potential agency conflicts stemming from divergence of interest between managers and shareholders. Unfortunately, when ownership is dispersed, shareholder control of managers tends to be weaker. The inadequacy of shareholder monitoring is due to the so-called free-rider problem (Grossman and Hart, 1980). That is, small shareholders are not interested in monitoring managers because they bear all the 
monitoring costs and share only a small proportion of the benefits. As a result, managers in widely-held corporations find it easier to pursue their interests even at the expense of shareholders.

The presence of large shareholders with greater controlling interest potentially solves the free rider problem. Since large shareholders have significant investments in the firm, they have an incentive to collect information and monitor management (Shleifer and Vishny, 1986). Large shareholders also have enough voting power to put pressure on management to act in the interest of shareholders (La Porta et al., 1999). Therefore, large shareholders have both the power and incentive to monitor managers.

Large shareholders can be families, government(s), institutional investors or banks. Given the significant investment in firms, all types of large shareholders should have the power and incentive to monitor managers. However, as noted by Tufano (1996) and Gugler (2001), each type of large shareholder may have different incentives and motivations (i.e., the identity of investors matters). The theoretical work of Gorton and Kahl (1999) shows that families are better monitors than other types of large shareholders. There are at least three reasons for this.

First, families deal with their own money in the firms they control. In his classic book The Wealth of Nations, Adam Smith (1776) argues that:

" The directors of such [joint-stock] companies however, being the managers of other people's money rather than of their own, it cannot well be expected that they should watch over it with the same anxious vigilance with which partners in a private copartnery frequently watch over their own “

Smith maintains that a necessary and sufficient condition for good monitoring is whether "monitors" watch "their own money" or not. Families certainly meet this condition as their wealth is strongly linked to the continuation of their companies, and therefore, they have a stronger incentive to monitor managers than dispersed shareholders.

Second, families are interested in the firm's survival as they often hold undiversified portfolios and because they seek to pass the firm to their heirs. Anderson and Reeb (2003a) argue that families view their firms as an asset to bequeath to family members or their descendents rather than wealth to be consumed during their lifetime. Specifically, family interests lie in passing the firm as a going concern to their heirs rather than merely passing their wealth. A firm's survival is thus a very important concern for families, suggesting that relative to other large shareholders, they potentially have longer time horizons and are more likely to ensure that managers maximise firm value.

Third, families usually control agency conflicts by placing their members in top management positions (Fama and Jensen, 1983; DeAngelo and DeAngelo, 1985; Denis and Denis, 1994). With family involvement in top management, there is greater alignment between the interest of shareholders and managers. The implicit contract among family members discourages managers from abusing their power and transferring corporate funds to themselves (Fama and Jensen, 1983). Severe misconduct leads to risk of dismissal from the job but also the risk of expulsion from the family. These penalties are drastic and form an effective deterrent to serious malfeasance (Pollak, 1985). 
Moreover, monitoring and disciplining managers in family controlled firms is potentially efficient because family members have excellent information about the firm (Dennis and Dennis, 1994; Smith and Amoako-Adu, 1999). The uniqueness of these family rewards and sanctions are not open to other institutions (Pollak, 1985).

In short, the nature of agency relationships in family firms is characterized by altruism. Altruism is a trait that positively links the welfare of an individual to the welfare of others (Becker, 1981). Altruism enables families to sacrifice their current consumption for the welfare of their own children or grandchildren. This dynastic consideration gives family firms direct, long-term interest for the benefit of the family's well being (Pollak, 1985). Altruism also increases communication and cooperation within the family firm, thereby potentially reducing information asymmetries among family agents and increases their use of informal agreements (Daily and Dollinger, 1992).

Gorton and Kale (1999) argue that institutional investors are basically synthetic large investors created by small investors in order to mimic the advantages of family control. Since institutional investors are run by professional managers, they are also agents with their own sources of agency conflict (Black, 1992). In certain types of institutional investors, such as public pension funds, this problem can be severe. Because public pension funds are often managed by officials with their own personal agendas, such as public office campaigners, their goals often do not maximise shareholder value (Romano, 1993). Therefore, institutional investors might encounter the "who monitors monitor problem" (Alchian and Demsetz, 1972) or "agents watching agents problem” (Black, 1992). A similar argument can be applied to governments.

Empirical evidence in the U.S. tends to support the argument that families are better monitors than other types of large shareholders. For example, Anderson and Reeb (2003a) and McConaughy et al. (1998) compared the performance of large family and non-family controlled firms and found that family controlled firms outperformed their non-family counterparts. Both McConaughy et al. and Anderson and Reeb argue that the results are consistent with the argument that founding-family firms have incentive structures that result in low agency costs.

While the argument that family firms reduce agency costs appears to be well reasoned, findings from recent empirical research question this view. Studies by Schulze et al. (2001) and by Gomez-Mejia et al. (2001) suggest that family businesses actually incur higher agency costs compared to non-family enterprises, since families are unwilling to fire incompetent family members.

Gomez-Mejia et al. (2001) compared the performance of Spanish media firms from 1966 to 1993. They discovered significant costs were incurred by family-owned firms as these firms were more reluctant to fire family CEOs. However, when such action was taken, the family firm's performance improved significantly. Gomez-Mejia et al. conclude that families are reluctant to 
strictly monitor, discipline, or fire family CEOs because they are family members.

Schultze et al. (2001) argue that the agency problem in private family firm is more difficult to manage because of selfcontrol and other problems engendered by altruism. They argue that private ownership insulates the firm from the disciplining role of external markets (i.e., market for corporate control and labour market). In addition, altruism negatively affects family firms. The parents' increased generosity causes their children to free-ride (i.e., squander their parent's money). This agency threat is likely to be more pronounced in family firms, because control over the firm's resources makes it possible for owner managers to be unusually generous to their children and relatives. Schultze et al.'s (2001) empirical results support this hypothesis.

Morck and Yeung (2004) explain other characteristics of family firms that might destroy firm value. They argue that family blockholders improve corporate governance in the United States and United Kingdom because they have large fortunes tied up in the firm, thus decreasing the likelihood of mismanagement. Legal protection in the U.S. and the U.K. is strong and prevents family firms from expropriating minority shareholders. Many family firms, especially in East Asia, employ control pyramid structures which allow families to control numerous firms without investing too much of their own wealth in each firm - conglomeration phenomenon. These structures create the same incentive problems which occur in widely-held firms. Insiders (such as the family) rather than professional managers spend outside shareholders' money on things they desire rather than on things that build firm value.
This is a result of weak investor protection in East Asia.

Several empirical studies support Morck and Yeung's (2004) argument. Claessens et al. (2002) investigate the role of pyramid structures in East Asian corporations. They find that firm value falls when the control rights of family shareholders exceed cash-flow ownership. Lins (2003) reproduced Claessens et al.'s research in emerging economies and found that the effect of pyramid structures was weaker in countries with better legal protection.

In short, the literature suggests that agency costs might be a two-edged sword for family businesses. Family firms that have some objective standards for monitoring the performance of family managers and are willing to enforce discipline, might realise the advantage of lower monitoring costs since the goals of owners and managers are aligned. However, those firms that allow nepotism without providing adequate monitoring might be at a competitive disadvantage (Dyer, 2003).

\section{Uniqueness of Family Firms and Its Influence on Corporate Decisions}

Families represent a special class of large shareholders that potentially have a unique incentive structure and power in the firm (Anderson et al., 2003). Theories of the firms suggest two main characteristics that distinguish families from other types of large shareholders or managers of widely-held firms. First, families have a stronger desire to maintain control to protect their highly valuable private benefits of control and firmspecific human capital. Second, with substantial wealth and human capital at risk, family owners tend to be more risk averse than non-family owners. These unique characteristics of family firms potentially make their corporate decisions different from those of non-family firms. 


\section{Families' Incentive to Control}

Families usually have more personal wealth tied to the firm. Using Forbes' Wealthiest Americans database to examine family ownership and firm performance, Anderson and Reeb (2003a) found that on average, families have more than 69 percent of their wealth invested in the firm, which suggests that families both value and have an incentive to maintain control.

Modern finance theory emphasises the benefits of portfolio diversification. By holding several shares in a portfolio, investment risk can be reduced. Some of the risks simply cancel out when one company does poorly and another does well, bringing the portfolio into equilibrium. From the perspective of financial returns, there is no benefit to concentrated shareholdings (Mayer, 2001).

The fundamental question is, what motivates families to forgo the benefits of diversification by concentrating their wealth into the stock of a single firm?

The family business literature suggests that families concentrate their shareholdings and maintain control because of their desire to transfer business to heirs, to hire relatives, and to enhance the family name through the success of the firm. All these private benefits are enjoyed by families as long as they maintain the majority vote. Another reason is to protect firm-specific human capital from hold-up action initiated by outsiders.

Empirical evidence supports the argument that family owners have a greater desire to maintain control. Denis and Denis (1994) studied majority-owned firms in the US and found that ownerspecific attributes (e.g., the identity of owners and their desire to control) is more important than firm-specific attributes (e.g., size and firm risk) in determining the choice of majority ownership. They conclude that majority ownership appears to be associated with individual owners and their desire to retain control, rather than with firm characteristics such as size or type of assets that makes majority ownership optimal. By maintaining majority control of the firm, family members protect their private benefits of control.

Empirical studies on dual class shares also support the conjecture that families have a stronger desire to control. In dual class recapitalisation, firms create second class common stocks that have limited voting rights and generally have a preferential claim to the firm's cash flows (Ogden et al., 2003). DeAngelo and DeAngelo (1985) studied the characteristics of firms that adopt dual class shares in the U.S., whereas Taylor and Whittered (1997) investigated those in Australia. Both studies found that the majority of dual class share firms were family controlled, indicating that families value control and issue non-voting stock to raise capital or provide liquidity without reducing control.

\section{Differences in Risk Preferences of Family and Non-family Owners/Managers .}

One of the main sources of agency cost of equity in diffusely held corporations are differences in risk preferences between shareholders and managers. Treynor and Black (1976) show that managers and shareholders potentially bear different levels of risk. The typical shareholder in widely-held corporations generally holds a well-diversified financial portfolio. Thus, investment in one particular firm represents a relatively small portion of the individual's overall wealth. The 
advantage of this type of investment is that project failure in any one firm has a relatively small negative effect on the individual's wealth. Using portfolio theory terminology, diversification eliminates industry and firmspecific risk and therefore, a well-diversified investor is primarily concerned with systematic risk, not total risk.

Monsen and Downes (1965) argue that managers of widely-held firms face asymmetry in their reward structure. Managers' incomes are not identical with the firm's profits and do not vary in any strict manner to the firm's profits. In contrast, a firm's failure to achieve predetermined performance targets, or in the extreme case of bankruptcy, seriously harms managers' current and future employment (and therefore their future income).

Successful managers are able to move from firm to firm, commanding a salary on the basis of past performance. Good reputation has positive market value which is part of the manager's human capital (Milgrom and Roberts, 1992). For many managers, their human capital is by far the most valuable asset they own because it affects future earning potential. Sutton and Callahan (1987) show that managers of bankrupted firms suffer substantial losses in reputation and selfesteem, indicating that financial distress is costly for managers. Gilson (1989) provides some evidence of the costs of financial distress for managers and reports that there is a higher probability that top executives lose their jobs. Moreover, he documents that none of the departing managers in his sample are placed in top positions at other publicly traded firms for three years.
The evidence provided by Sutton and Callahan (1987) and Gilson (1989) suggests that the costs of financial distress for managers are significantly high. Unfortunately, such risk cannot be effectively diversified by managers in their personal portfolios, since human capital is essentially nontransferable (Amihud and Lev, 1981; Milgrom and Roberts, 1992).

Accordingly, managers tend to be more risk averse than shareholders of diffusely held firms. Risk-averse managers have an incentive to diversify their employment risk by using a firm's investment and financial policies to reduce total risk of the firm. It should be noted that such actions may not necessarily be in the best interest of shareholders. Evidence tends to support the conjecture that managers tend to choose firm risk reduction strategies at the expense of shareholders. For instance, Amihud and Lev (1981) found that conglomerate mergers are more numerous when shareholdings are widely dispersed. In addition, recent evidence in the U.S. indicates that returns to shareholders from diversified corporations are significantly lower than those of undiversified firms in the same industry, and that shareholder returns decrease as firms become increasingly diversified (Lang and Stultz, 1994; Comment and Jarrell, 1994; Berger and Ofek, 1994).

The self-serving decisions by managers are relatively freely exercised in widely-held corporations due to the free rider problem. When ownership is concentrated, the controlling stockholders are generally able to exert a tighter control on managers' decisions and to assess 
whether the decisions are in the interest of shareholders. Thus, large shareholders are able to prevent managers' risk reduction strategies that are against the interest of shareholders. However, the actual control and action by controlling shareholders also depends on their degree of diversification.

Large shareholders such as institutional investors and the state are generally well-diversified and primarily concerned with systematic risk. Therefore, if they have an incentive to use their power, it is likely that they can minimise self-serving decisions driven by the risk preferences of managers. Friend and Lang's (1988) analysis suggests that the presence of large external shareholders limits management's discretion in seeking sub-optimal risk reducing strategies (i.e., lower debt levels).

In contrast, families have disproportionate amounts of their wealth invested in the firm, in the form of financial and firm-specific human capital and are therefore relatively undiversified (Short, 1994). Palia and Ravid (2002) argue that founders of family firms are characterised as persons with the 'best idea', whose value added is based on the match between the firm and the founder's special skill. This special skill attached to a certain firm is referred to as firm-specific human capital. The important attribute of this firm-specific human capital is its irreversibility, that is, a fraction of the value cannot be recovered by reselling. In addition, firm-specific human capital is less productive when used outside a particular firm. As a result, firm financial distress will put this human capital at risk.
Families usually not only have significant firm-specific human capital invested in the firm, but also have great personal wealth tied to the firm. Unfortunately, families cannot effectively diversify the risk of this investment due to financial constraints and therefore they often hold undiversified portfolios (Agrawal and Nagarajan, 1990). The combination of undiversified financial and firm-specific human capital suggests that family shareholders are more likely to be more risk averse than other types of large shareholders or managers of widely-held corporations.

Empirical evidence shows that the uniqueness of family controlled firms result in the differences in both firm performance and firm decision making. In a panel study on S\&P 500 firms, Anderson and Reeb (2003a) find that family firms perform better than non-family firms, both in terms of market and accounting measures. Their results point in the same direction as findings by McConaughy et al. (1998). Morck et al. (2000) show contradictory evidence for Canada, arguing that family ownership leads to poor financial performance. Their results suggest that family control by heirs leads to slower growth because of inefficiencies that are due to entrenchment, high barriers against outside control and low investment in innovation. Similarly, Claessens et al. (2002) show the negative impact of family control in East Asia on firm performance.

In term of corporate decision making, family control also have different impact on investment policy (Anderson and Reeb, 2003b; Anderson et al., 2009), capital structure decisions (Agrawal and 
Nagarajan, 1990 ; Mishra and McConaughy, 1999; Anderson and Reeb, 2003b; Setia-Atmaja et al., 2009), dividend policy (Setia-Atmaja et al., 2009), agency cost of debt (Anderson et al., 2003), corporate disclosure (Alia et al., 2007), earning quality (Wang, 2006), insurance policy (Mayers and Smith, 1990), corporate governance (Anderson and Reeb, 2004; Setia-Atmaja et al., 2009) and takeover activity (Boehmer, 2000 ; Holderness and Sheehan, 1985).

\section{CONCLUSION}

Families represent a special class of large shareholders that potentially have a unique incentive structure and power in the firm (Anderson et al., 2003). Families have a stronger desire to maintain control to protect their highly valuable private benefits of control and firm-specific human capital. In addition, family owners tend to be more risk averse than non-family owners as they have substantial wealth and human capital invested at the firm. These unique characteristics of family firms potentially make their performance and their corporate decisions making different from those of non-family firms. The empirical evidences tend to support this argument. As it is only in the last decade that serious academic research on family firms has been undertaken (Chami, 1999), further quantitative and qualitative research to establish the relations between family control and several aspects of corporate decision making in different institutional and cultural settings remains to be done.

\section{REFERENCES}

Agrawal, A. and N. Nagarajan, 1990, Corporate capital structure, agency costs, and ownership control: The case of all-equity firms, Journal of Finance 45, 1325-1331.

Alchian, A.A. and H. Demzetz., 1972, Production, information costs, and economic organization, American Economic Review, 62, 777-795.

Alia, A., T.Y, Chen, and S. Radhakrishnan, 2007, Corporate disclosures by family firms, Journal of Accounting and Economics 44, 238-286

Amihud, Y. and B. Lev, 1981, Risk reduction as a managerial motive for conglomerate mergers, Bell Journal of Economics 12, 605-617.

Anderson, R.C., S.A. Mansi, and D.M. Reeb, 2003, Founding family ownership and the agency cost of debt, Journal of Financial Economics 68, 263-285.

Anderson, R.C. and D.M. Reeb, 2003a, Founding family ownership and firm performance: Evidence from the S\&P 500, Journal of Finance 58, 1301-1328.

Anderson, R.C. and D.M. Reeb, 2003b, Founding family ownership, corporate diversification and firm leverage, Journal of Law and Economics (October), 653-684.

Ang, J.S., R.A. Cole and J.W. Lin, 2000, Agency costs and ownership structure, Journal of Finance 55, 81-106.

Barclay, M. J. and C. G. Holderness, 1992, The law and large-block trades, Journal of Law and Economics 35, 265-294.

Barnea, A., R. Haugen and L.W. Senbet , 1980, A rationale for debt maturity structure and call provisions in the 
agency theoretic framework, Journal of Finance 35,1223-1234.

Barney, J.B., 2002, Gaining and sustaining competitive advantage, Prentice Hall: Upper Saddle River, NJ

Becker, G.S., 1964, Human Capital, Columbia University Press: New York.

Becker, G.S., 1981, A treatise on family, Harvard University Press: Cambridge MA.

Berger, P. and E. Offek, 1994, Diversification's effect on firm value, Journal of Financial Economics 37, 3965.

Berle, A. A. and G. C. Means, 1932, The modern corporation and private property. New York, Macmillan.

Besanko, D., D. Dranove and M. Shanley, 2004, Economics of strategy, Wiley: New Jersey

Black, B., 1992, The value of institutional investor monitoring: the empirical evidence, UCLA Law Review 39, 895-939.

Blair, M.M., 1995, Ownership and control, The Brooking Institution: Washington DC.

Boehmer, E., 2000, Business groups, bank control, and large shareholders: An analysis of German takeovers, Journal of Financial Intermediation 9, 117-148

Bolton, P. and D.S. Scharfstein, 1998, Corporate finance, the theory of the firm, and organizations, Journal of Economic Perspective 12, 95-114

Capulong, M., D. Edward, D. Webb, and J. Zhuang (eds), 2000, Corporate governance and finance in East Asia : A study of Indonesia, Republic of Korea, Malaysia, Phillipines and Thailand, Asian Development Bank : Manila.

Castanias, R.P. and C.E. Helfat, 1992, Managerial and windfall rents in the market for corporate control, Journal of Economic Behavior and Organization 18, 153-184.
Chami, R., 1999, What's different about family businesses? IMF Working paper

Cheung, C.S. and J.C. Gaa, 1989, Controlling opportunistic behavior in corporate governance: The role of disproportionate voting shares and coat-tail provisions, Journal of Institutional and Theoretical Economics 145, 438-450.

Claessens, S., S. Djankov, J. Fan and L.H.P. Lang, 2002, Disentangling the incentive and entrenchment effects of large shareholdings, Journal of Finance 31, 2741-2771.

Coase, R., 1937, The nature of the firm, Economica November, 386-405.

Comment, R. and G. A. Jarrel, 1994, Corporate focus and stock returns, Journal of Financial Economics 37, 6787.

Daily, C.M. and M.J. Dollinger, 1992, An empirical analysis of ownership structure in family and professionallymanaged firms, Family Business Review 5, 117-136.

DeAngelo, H. and L. DeAngelo, 1985, Managerial ownership of voting rights: a study if public corporation with dual classes of common stock, Journal of Financial Economics 14, 33-39.

Denis, D. and D. Denis, 1994, Majority-owner managers and organizational efficiency, Journal of Corporate Finance 1, 91-118.

Douma, S. and H. Schreuder, 2003, Economic approaches to organizations, Financial Times Prentice Hall: Harlow

Dyck, A. and L. Zingales, 2003, Private benefits of control: An international comparison, Journal of Finance 59, 537600.

Dyer, W.G., 2003, The family: Missing variables in organizational research, Entrepreneurship Theory and Practice 27, 401-416 
Ehrhardt, O. and E. Nowak, 2003, Private benefits and minority shareholder expropriation, Working Paper.

Eisenhardt, K., 1989, Agency theory: An assessment and review, Academy of Management Journal 14, 57-74.

Faccio, M., L. H. P. Lang, L. Young, 2001, Dividends and expropriation, American Economic Review 91, 54-78.

Faccio, M., and L. Lang, 2002, The ultimate ownership of Western European Corporations, Journal of Financial Economics 65, 365-395.

Fama, E. and M. Jensen, 1983, Separation of ownership and control, Journal of Law and Economics 26, 301-325.

Fan, J.P.H. and T.J. Wong, 2002, Corporate ownership structure and the informativeness of accounting earnings in East Asia, Journal of Accounting and Economics 33, 401-425.

Foss, N.J., H. Lando and S. Thomsen, 2000, The theory of the firm in Bouckaert, B. and D. Gerrit (eds.), Encyclopedia of Law and Economics, Elgar, Cheltenham

Friend, I. and L. Lang, 1988, An empirical test if the impact of managerial self-interest in corporate capital structure, Journal of Finance 43, 271-281.

Gilson, S., 1989, Management turnover and financial distress, Journal of Financial Economics 25, 241-262.

Gomez-Mejia, L.R., M. Nunez-Nickel, I. Gutierrez, 2001, The role of family ties in agency contact, Academy of Management Journal 44, 81-95.

Gomez-Mejia, L.R., M. Nunez-Nickel, I. Gutierrez, 2003, The determinants of executive compensation in familycontrolled public corporations, Academy of Management Journal 46, 226-237.

Gorton, G. and M. Kahl, 1999, Blockholder identity, equity ownership structures, and hostile takeovers, NBER Working Paper Series No. 7123.

Grossman, S. and O. Hart, 1980, Takeover bids, the free-rider problem and the theory of corporation, Bell Journal of Economics 11, 42-64.

Grossman, S. and O. Hart, 1986, The costs and benefits of ownership: A theory of vertical and lateral integration, Journal of Political Economy 94, 691-719.

Gugler, K., 2001, Corporate governance and economic performance, Oxford University Press : Oxford.

Harris, D. and C. Helfat, 1997, Specificity of CEO human capital and compensation, Strategic Management Journal 18, 895920.

Hart, O., and J. Moore, 1990, Property right and the nature of the firm, Journal of Political Economy 98, 1119-1158

Holderness, C.G., 2003, A survey of blockholders and corporate control, Economic Policy Review 9, 51-63.

Holderness, C.G. and D. Sheehan, 1985, Raiders or saviors? The evidence on six controversial investors, Journal of Financial Economics 14, 555-579

Holderness, C.G. and D. Sheehan, 1988, The role of majority shareholders in publicly held corporations, Journal of Financial Economics 20, 317-346.

Jensen, M., 1983, Organization Theory and Methodology, The Accounting Review 57, 319-339.

Jensen, M. and W. Meckling, 1976, Theory of the firm: Managerial behaviour, agency costs, and ownership structure, Journal of Financial Economics 3, 305-360.

Klein, B., R. Crawford and A. Alchian, 1978, Vertical integration, appropriable rents, and the competitive contracting process, Journal of Law and Economics 21, 297326.

Lang, L. and R. Stultz, 1994, Tobin Q, corporate diversification, and firm The Uniqueness of Family Firms 
performance, Journal of Political Economy 102, 1248-1280.

LaPorta, R., F. Lopez-de-Silanes, A. Shleifer, and R. Vishny, 1999, Corporate ownership around the world, Journal of Finance 54, 471-518.

Lins, K, 2003, Equity ownership and firm value in emerging markets, Journal of Financial and Quantitative Analysis 38, 159-184.

Mayer, C., 2001, Firm control in Corporate governance: Essay in honor of Horst Albach. J. Schwakbach (ed), Springer.

Mayers, D. and C.W. Smith, 1990, On the corporate demand for insurance: Evidence from the reinsurance markets, Journal of Business 63, 19-40.

McConaughy, D.L., Mc. Walker, G.V. Henderson and C.S. Mishra, 1998, Founding family controlled firms: Efficiency and value, Review of Financial Economics 7, 1-19.

Mehran, H., 1992, Executive incentive plans, corporate control and capital structure. Journal of Financial and Quantitative Analysis 27, 539-560.

Mehran, H., R.A. Taggart, and D. Yermack, 1999, CEO ownership, leasing and debt financing, Financial Management

Milgrom, P. and J. Roberts, 1992, Economics, Organization and Management, New Jersey, Prentice Hall.

Mishra, C. S. and D. L. McConaughy, 1999, Founding family control and capital structure: The risk of loss of control and the aversion to debt, Entrepreneurship Theory and Practice (Summer), 53-64.

Morck, R., and B. Yeung, 2003, Agency problems in large family business groups. Entrepreneurship Theory and Practice (Summer), 367-382.

Morck, R. and B. Yeung, 2004, Special issues relating to corporate governance and family control, World Bank Policy Research Working Paper 3406

Ogden, J.P., F.C. Jen and P.F. O'Connor, 2003, Advanced corporate finance: policies and strategies, Prentice Hall: Upper Saddle River, N.J.

Palia, D., Ravid, S.A., 2002, The role of founders in large companies: Entrenchment or valuable human capital?, Rudgers University Working Paper.

Pollak, R., 1985, A transaction cost approach to families and household, Journal of Economic Literature 23, 581-608.

Romano, R., 1993, Public pension fund activism in corporate governance reconsidered, Columbian Law Review 93, 795-853.

Schulze, W.S., M.H. Lubatkin, R.N. Dino, 2001, Agency relationship in family firms: Theory and evidence, Organizational Science 12, 99-116.

Setia-Atmaja, L., G. A. Tanewski and M. Skully, 2009, The role of dividents, debt and board structure in the governance of family controlled firms. Journal of Business Finance \& Accounting

Shleifer, A. and R. Vishny, 1986, Large shareholders and corporate control, Journal of Political Economy 95, 461488.

Short, H., 1994, Ownership, control, financial structure and performance of firms, Journal of Economic Surveys 8, 203249.

Smith, C.W., 1990, The theory of corporate finance: A historical overview, in The modern theory of corporate finance, Smith, C.W. (ed), McGraw-Hill : New York.

Smith, B.F. and B. Amoako-Adu, 1999, Management succession and financial performance of family controlled firms, 
Journal of Corporate Finance 5, 341368.

Steier, L., 2003, Variants of agency contracts in family-financed ventures as a continuum of familiar altruistic and market rationalities, Journal of Business Venturing 18, 597-618.

Sutton, R. and A. Callahan, 1987, The stigma of bankruptcy: Spoiled organizational image and its management, Academy of Management Journal 30, 405-436.

Taylor, S., and G. Whittered, 1997, Security design and the allocation of voting rights: Evidence from the Australian IPO market, Journal of Corporate Finance 4, 107-131.

Treynor, J.L. and F. Black, 1976, Corporate investment decision in S.C. Myers (ed), Modern development in financial management, Praeger Publishers : New York.
Tufano, P., 1996, Who manages risk? An empirical examination of risk management practices in the gold mining industry, Journal of Finance 51, 1097-1137.

Wang, D., 2006, Founding Family Ownership and Earning Quality, Journal of Accounting Research Vol. 44 No. 3

Williamson, O. E., 1975, Markets and Hierarchies: Analysis and Antitrust Implications, Free Press: New York.

Williamson, O. E., 1985, The Economic Institutions of Capitalism, Free Press: New York.

Zingales, L., 1998, Corporate governance in The new Palgrave dictionary of economics and law, P. Newman (ed). London, Macmillan.

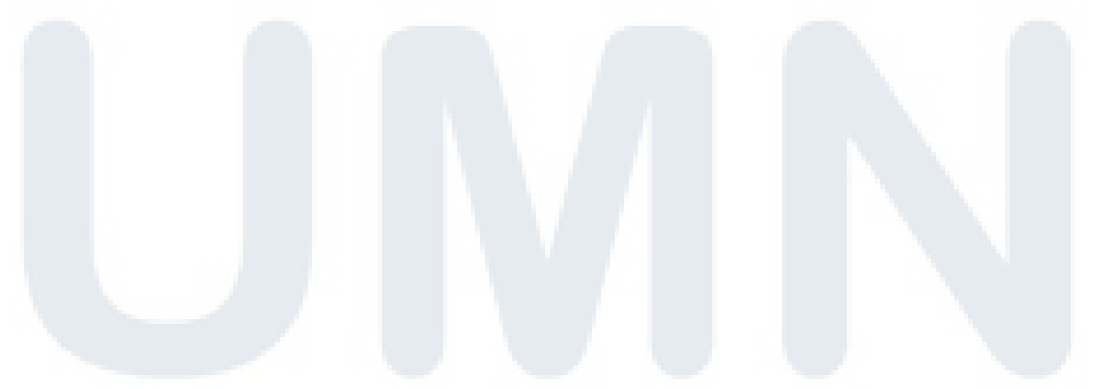

